\title{
The MINT Countries: A Regression Analysis of the Selected Economic Features
}

\author{
${ }^{1}$ Filip Kokotović, ${ }^{2}$ Petar Kurečić, \\ ${ }^{1}$ University College of International Relations and Diplomacy Dag Hammarskjöld, Zagreb, Ilica 242, Croatia, \\ ${ }^{2}$ University North, Department of Business Economics, Varaždin, 104 Brigade 3, Croatia
}

\begin{abstract}
The BRIC countries - Brazil, Russia, India, and China - are being considered as potential powerhouses of the world economy. These countries have formalized their cooperation, and later, with the joining of South Africa, became the BRICS. They are often perceived as proponents of a multipolar world, choosing multipolarity over unipolarity, and supporting political institutions and organizations, at the same time creating alternative financial institutions to the hegemonic ones (the IMF and the World Bank), still dominated by the developed economies of the Western countries. So, what about a different group of countries, called the MINT countries or simply the MINTs that are emerging, growing economies, are heterogeneous as BRICS, but not nearly as large and powerful, and are located on four different continents, with no formal cooperation between themselves such as the BRICS? This article analyses the basic economic trends in the MINT countries by analyzing the linear relationship between GDP as the dependent variable and household consumption, foreign direct investment and government consumption as the independent variables. The general model is as follows: $\Delta \log \mathrm{GDP}_{\mathrm{t}}=\alpha_{0}+\alpha_{1} \Delta \log \mathrm{FDI}_{\mathrm{t}}+\alpha_{2} \Delta \log \mathrm{PC}_{\mathrm{t}}+\alpha_{3} \Delta \log \mathrm{GC}_{\mathrm{t}}+\varepsilon_{\mathrm{t}}$. The analysis was conducted using ordinary least squares (OLS) regression. By conducting this analysis, it is possible to conclude that the MINT countries have significant differences in regards to the statistical relevance of the chosen independent variables. One of the rare common traits of these four economies is that FDI does not seem to have a statistically significant impact on their development. This article concludes that the MINT countries may have a significant role in international relations as regional powers, but they do not have the economic or political traits necessary to challenge the BRICS countries significantly.
\end{abstract}

Keywords: The MINT Countries, OLS Regression Model, Foreign Direct Investment (FDI), GDP Growth

\section{Introduction}

Since 2001 the BRIC countries - Brazil, Russia, India, and China - are being considered as a potentially significant and influential block in international relations. They are often perceived as proponents of a multipolar world, choosing multipolarity over unipolarity, and supporting political institutions and organizations, at the same time creating alternative financial institutions to the hegemonic ones (the IMF and the World Bank), still dominated by the developed economies of the Western countries.

The Goldman Sachs economist Jim O’Neill, who has now identified the so-called MINT countries - Mexico, Indonesia, Nigeria and Turkey - as emerging economic giants, coined the term ${ }^{1}$. So, what about a different group of countries, called the MINT countries or simply the MINTs that are emerging, growing economies, are heterogeneous as BRICS, but not nearly as large and powerful, and are located on four different continents, with no formal cooperation between themselves such as the BRICS?Indonesia, Nigeria, and Turkey also have double-digit growth of between $11 \%$ and

\footnotetext{
${ }^{1}$ See: http://www.bbc.com/news/magazine-25548060 (Retrieved 16/03/2016).

Jim O'Neill also proposed the new term MIST, for Mexico, Indonesia, South Korea, and Turkey.

See: http://www.geopoliticalmonitor.com/backgrounder-mist-countries-4746/ (Retrieved 17/03/2016).
} 
$15 \%$. Mexico is the laggard at just over 7 percent, but this is still stronger than that worldwide figure of $4 \%$. Again, these are measured in local currency - apart from Nigeria for which we record transactions in USD - as, in our view, local currency provides a clearer measure of actual investment inthe country. So clearly, the MINT nations are ones to watch, but our observatories also show strong growth in local spending on technical applications in, for example, Vietnam $(16 \%)$ and South Africa (14\%) - so do not be distracted by a convenient acronym ${ }^{2}$.

Why are these countries then important for the world economy and the world in general then, and up to what level? The first question is, in other words, why should we analyze the MINT countries i.e. the MINT economies? There are a couple of reasons that need to be emphasized here - economic, demographic, and political. The second question, on which the quantitative analysis seeks to provide an answer, is the following: Is the classification of these countries as a group (from a perspective of economic science, as an object of study for the researchers primarily, since their formal cooperation is not significant) justified?

The MINT countries in 2014 comprised about 633 million people (Indonesia 254.5 million, Nigeria 177.5 million, Mexico 125.4 million, and Turkey 75.9 million $^{3}$ ) with a tendency of steady, rapid growth. Median age population (2015 est.) for these countries shows that these countries have younger populations ${ }^{4}$ (Indonesia 29.6 years, Mexico 27.6 years, Nigeria only 18.2 years, and Turkey 30.1 years) compared to that of the European countries (and even the P.R. China with 36.8 years, not to mention Russia with 39.1 years). There are various projections, but according to the Population Reference Bureau, in 2050, Nigeria should have 397 million people, and Indonesia 366 million $^{5}$. So, in only these two countries, according to the projection, more than 330 million inhabitants should be added to their populations. This predicted occurrence of such a demographic "shock" in these countries, of so many young people that will seek jobs ${ }^{6}$ and a better future, poses a serious threat to the living standard in these countries, which is even now well below the world average. Therefore, despite the fact the aggregate economies will grow in the next couple of decades, we can expect threats to the social cohesion, cramped living space, destruction of the natural habitats and resource extraction that could (and probably will) result in the continuance of the "resource curse" (especially in Nigeria) $)^{7}$.

According to the Goldman Sachs, in 2012, Mexico was the $14^{\text {th }}$ world economy, Indonesia $16^{\text {th }}$, Turkey $17^{\text {th }}$, and Nigeria $39^{\text {th }}$. If we accept the World Bank data for 2014 on GDP at market prices (current US\$) ${ }^{8}$, the position of Nigeria was much better, putting it on the $21^{\text {st }}$ place in the world. Turkey was $17^{\text {th }}$, Indonesia $16^{\text {th }}$, and Mexico $15^{\text {th }}$ world economy, according to the same database. The projections for 2050 predict that Mexico will be the eighth economy in the world, Indonesia $9^{\text {th }}$, Nigeria $13^{\text {th }}$, and Turkey $14^{\text {th }}$. Therefore, it is evident that the relative position (as well as the absolute size of course) of the MINT economies should improve. Hence, it is measured in absolute indicators (GDP); the demographic growth will also play an invaluable role in this continuous growth. Nevertheless, it

\footnotetext{
${ }^{2}$ http://www.cambashi.com/contentmgr/showdetails.php/id/2513/page/3 (Retrieved 20/03/2016).

${ }^{3}$ http://data.worldbank.org/indicator/SP.POP.TOTL/countries/1W?display=default (Retrieved 16/03/2016).

${ }^{4}$ Based upon Duroteye (2004:100): "One of the main determinants of classifying the MINT countries as potential economic power blocs is the young population of these countries, which is considered an asset both at the present and in the future. Youth are expected at the forefront of global social, economic and political developments. In addition to their intellectual contribution and their ability to mobilize support, young people bring unique perspectives that propel any society to greater heights. The progress of any society is based therefore, among other elements, on each society's capacity to involve young women and men in building and designing the future. However, the youth of the MINT countries face many challenges, which the governments, the private sector and civil society organizations should deal with if the youth would become an asset and engine of economic growth."

${ }^{5}$ http://money.cnn.com/2015/08/18/news/countries-with-biggest-populations/ (Retrieved 16/03/2016).

${ }^{6}$ Accirding to Duroteye, (2014b:124): "Unemployment among Indonesia's youth aged 15 to 24 is at an unusually high level of $21.6 \%$. Turkey's youth unemployment rate stands at $17 \%$. Nigeria's youth unemployment rate is well over $50 \%$ as will be shown later in this paper. Interestingly, Mexico's figure of youth unemployment rate stands at less than $10 \%$."

${ }^{7}$ Watts, M. (2004). Resource curse? Governmentality, oil and power in the Niger delta. Geopolitics, 9 (1) 50-80.

Kurečić, P., Kozina, G. (2014). Natural Resources Management as a Factor of Underdevelopment and Social Inequality in the Gulf of Guinea Region. Proceedings of the eighth International Scientific Conference on Economic and Social Development and fourth Eastern European ESD Conference: Building Resilient Economy, Zagreb, Croatia: 118-127, http://www.esdconference.com/Book_of_Proceedings_esd_ZG_2014.pdf.

${ }^{8}$ http://data.worldbank.org/indicator/NY.GDP.MKTP.CD/countries/1W?display=default (Retrieved 16/03/2016).
} 
would be fascinating to see what will be the GDP per capita, GINI index, and HDI in these countries (especially Nigeria and Indonesia) and how will it position them in $2050^{9}$.

Nevertheless, the prices of commodities in general, and especially fuels (oil and gas) have decreased sharply since 2014 , and there are no credible signs that it will grow significantly anytime soon. Nigeria, as a "mono economy" entirely dependent on oil as its practically only export product is suffering the most. Mexico is a significant oil exporter as well, albeit it is far from being dependent on oil exports like Nigeria. It is the sixth largest oil-exporting nation in the world and along with Canada is the largest foreign source of oil to the United States. Indonesia was the only Asian member of the Organization of Petroleum Exporting Countries (OPEC) outside of the Middle East until 2008 and is currently a net oil importer (Durotoye, 2014: 101). Turkey, on the other hand, profits from the cheap oil and gas, since it is a large net importer. Concurrently, on the downside, its tourism suffers because of terrorism and the War in Syria. The mid-term projections about the growth of the MINT economies must take all these trends and realities into consideration $^{10}$. Therefore, long-term projections should probably be more optimistic than the short- and mid-term ones.

Table 1: The BRICS and the MINTs: main similarities and differences

\begin{tabular}{|c|c|}
\hline The BRICS & The MINTs \\
\hline $\begin{array}{l}\text { There were four BRIC countries, and later with the } \\
\text { joining of South Africa; they became the five BRICS } \\
\text { countries. }\end{array}$ & There are four MINT countries. \\
\hline $\begin{array}{l}\text { The BRICS countries are located on four continents } \\
\text { (Asia, Europe, Africa, and South America). }\end{array}$ & $\begin{array}{l}\text { The MINT countries are located on four continents } \\
\text { (Europe, Asia, North America, and Africa). }\end{array}$ \\
\hline $\begin{array}{l}\text { Three BRICS countries are net natural resource } \\
\text { exporters (Brazil, Russia, and South Africa), and two } \\
\text { are net large natural resource importers (India, and } \\
\text { the P.R. China). At the same time, India and the P.R. } \\
\text { China are among the biggest exporters of industrial } \\
\text { products. }\end{array}$ & $\begin{array}{l}\text { Three MINT countries are net natural resource } \\
\text { exporters (Indonesia, Mexico, and especially } \\
\text { Nigeria). Turkey is net natural resource importer, at } \\
\text { the same time being crucial and booming exporter of } \\
\text { industrial products. }\end{array}$ \\
\hline $\begin{array}{l}\text { Demographically, the BRICS countries are } \\
\text { comprised of three very young and dynamic } \\
\text { populations (South Africa, India, and Brazil), one } \\
\text { mature population (the P.R. China), and one aging, } \\
\text { stagnating population (Russia). }\end{array}$ & $\begin{array}{l}\text { The MINT countries have very dynamicpopulations, } \\
\text { whose median age puts them in the group of young } \\
\text { populations. A very high population growth is } \\
\text { expected even in the next couple of decades. }\end{array}$ \\
\hline $\begin{array}{l}\text { As of } 2014 \text {, according to the World Bank data on } \\
\text { GDP in market prices, the BRICS comprised the } \\
\text { world's second (the P.R. China), seventh (Brazil), } \\
\text { ninth (India), tenth (Russia), and } 30^{\text {th }} \text { (South Africa) } \\
\text { economy. }\end{array}$ & $\begin{array}{l}\text { As of } 2014 \text {, according to the World Bank data on } \\
\text { GDP in market prices, the MINTs comprised the } \\
\text { world's } 15 \text { th } \text { (Mexico), } 16^{\text {th }} \text { (Indonesia), } 17^{\text {th }} \\
\text { (Turkey), and } 21^{\text {st }} \text { (Nigeria) economy. }\end{array}$ \\
\hline
\end{tabular}

There are not many academic studies that are specifically devoted to the MINT countries (and the MINT economies as well), especially compared to the number of the studies dedicated to the BRICS. This is quite reasonable, if we consider the time (much sooner than the MINTs) when the BRIC(S) emerged as a "bloc," the overall importance of their economies, their military power, and political influence. We emphasize the study of Akpan, Salisu, and Asongu (2014) that examines the determinants of FDI in Fast-Growing Economies, comparing the BRICS and the MINTs. Also, we have to point out two short, mainly descriptive studies by Durotoye (2014a, b), that explore the prospects and challenges of the MINTs as an "emerging economic power bloc", and the crisis of youth unemployment in the MINT

\footnotetext{
${ }^{9}$ As of 2012, in terms of wealth the situation is the following: In terms of wealth, Mexico and Turkey are at about the same level, earning annually about $\$ 10,000(£ 6,100)$ per head. This compares with $\$ 3,500(£ 2,100)$ per head in Indonesia and $\$ 1,500(£ 900)$ per head in Nigeria, which is on a par with India. They are a bit behind Russia - $\$ 14,000(£ 8,500)$ per head - and Brazil on $\$ 11,300$ $(£ 6,800)$, but still a bit ahead of China - $\$ 6,000(£ 3,600)$.

http://www.bbc.com/news/magazine-25548060 (Retrieved 16/03/2016).

${ }^{10} \mathrm{http}: / /$ www.theneweconomy.com/business/is-mint-the-next-bric (Retrieved 17/03/2016).
} 
countries. Öztürk and Yildirim (2015) have performed a research studying environmental Kuznets curve ${ }^{11}$ in the MINT Countries, by testing evidence of long-run panel causality test, and obtained ambiguous results. They also stated that "According to (Jim) O'Neill, MINT countries have some advantages that could potentially propel them to the world's ten largest economies in three decades (177). A study done by Simplice (2015) is focused on the drivers of growth in fast emerging economies, providing us with the comparison between the BRICS and the MINT countries. Simplice uses a dynamic instrumental quantile approach, in which the instrumental variable (IV) quantile regression approach is complemented with two-stage-least-squares and IV least absolute deviations ${ }^{12}$.

Nevertheless, contrary to the statement that "the MINTs are the new BRICS"13, we do not share this opinion, and some of the reasons are found in the sheer numbers pointed out in the introduction, as well as in the quantitative research that makes the backbone of this paper.

\section{Methodology}

The data were extracted from the World Bank database, the values of GDP in current dollars, and the value of household consumption, general government consumption and the net inflow of FDI in current dollars for the past 25 years. The data was then corrected for inflation using the GDP deflator, also acquired from the World Bank database. ${ }^{14}$ Based on this data, the log difference ${ }^{15}$ of the four variables was calculated to obtain statistically significant results regarding variable stationery. In this model, the log difference of real GDP $(\Delta \log$ GDP $)$ is the dependent value, while the explanatory variables are the log difference of FDI net inflow $(\Delta \log$ FDI), the log difference of household consumption $(\Delta \log \mathrm{PC})$ and the log difference of government consumption $(\Delta \log \mathrm{GC})$. From that point, the models for Tukey, Nigeria, and Mexico are considered. ${ }^{16}$

The general model is as follows:

$\Delta \log \mathrm{GDP}_{t}=\alpha_{0}+\alpha_{1} \Delta \log \mathrm{FDI}_{t}+\alpha_{2} \Delta \log \mathrm{PC}_{t}+\alpha_{3} \Delta \log \mathrm{GC}_{t}+\varepsilon_{t}(1)$

The model for Indonesia is slightly different because the FDI net inflow value for several years was negative. To preserve the methodology used for the other countries, a constant was added before calculating the log difference in a view to making the value of the FDI net inflow positive. That same value was added to all of the other variables for that country in the model to preserve the possible linear relationship between the variables.

The model for Indonesia is as follows:

$\Delta \log \left(\mathrm{GDP}_{t}+\beta\right)=\alpha_{0}+\alpha_{1} \Delta \log \left(\mathrm{FDI}_{t}+\beta\right)+\alpha_{2} \Delta \log \left(\mathrm{PC}_{t}+\beta\right)+\alpha_{3} \Delta \log \left(\mathrm{GC}_{t}+\beta\right)+\varepsilon_{t}(2)$

\footnotetext{
${ }^{11}$ The environmental Kuznets curve hypothesis (EKC) urges that there is an inverse-U-shaped relationship between carbon dioxide emission per capita and income per capita. So the EKC argument seeks an answer for

the question of "does economic growth need to be slowed in order to avoid increasing harm to the environment" (Carson 2010,3). In: Öztürk and Yildirim (2015: 176).

${ }^{12}$ The following conclusion are reached by Simplice (2015): first, while "Gross FDI has a negative effect on economic growth, the impact of Net FDI is positive, with a higher magnitude in top quantiles of the distributions. Second, the positive effect of natural resources is more apparent in countries with low initial growth levels. Third, the impact of telecommunications infrastructure is not very significant. Fourth, whereas the incidence of bank credit is positive for GDP growth, it is negative for real GDP output. Fifth, while trade openness is positive in bottom quantiles of GDP growth, but for the highest quantile in real GDP output, it is consistently negative on real GDP output. Sixth, while the incidence of political stability is negative on GDP growth, it is positive on real GDP output, with the negative (positive) effect apparent only in top (bottom) quantiles of GDP growth (real GDP output)."

${ }_{13}$ http://www.tmf-group.com/en/media-centre/news-and-insights/january-2014/refreshing-economic-news-mint-is-the-new-brics (Retrieved 20/03/2016).

${ }^{14}$ Using the formula variable ${ }_{t} *$ GDP deflator ${ }_{\text {base year }} /$ GDP deflator ${ }_{t}$ where the base year was the value of the GDP deflator for 2014 and $t$ are the value of the years from 1991-2014.

${ }^{15} \mathrm{~A}$ commonly used technique, calculating the first difference of logarithms is becoming as commonplace for achieving stationarity in times series models as percentage points. In this paper, the natural logarithm (base e) was calculated for all values.

${ }^{16}$ In the paper, it was attemptedat first to construct an average model for the MINT countries by averaging the values of GDP, net inflow and government and household consumption. The issue with the constructed model was that two of the variables presented issues regarding variable stationary. Therefore, it was concluded that individual testing for each of the MINT countries would be more representative and provide more statistically significant results rather than change the methodology of the paper.
} 
In these models, aside from the variables that were previously explained, $\alpha_{0}$ is the constants, $\alpha_{1,3}$ are the trends and $\varepsilon_{\mathrm{t}}$ is the error term and $t$ represents the time period that was observed in the paper. The $\beta$ coefficient ${ }^{17}$ is the value that was necessary to make the net FDI inflow have a positive value for Indonesia. To test the stationary of the independent and explanatory variables, the Augmented Dickey-Fuller (ADF) test, introduced by Dickey and Fuller (1979), was used. After performing the tests on the variables to confirm their stationary, the Ordinary least squares (OLS) method was used to obtain the values of $\alpha$ coefficients. The models were then tested for the presence of autocorrelation and heteroscedasticity. This was determined by testing the models for autocorrelation by interpreting the Durbin Watson statistic and using the Breusch-Godfrey serial correlation Lagrange multiplier, while the presence of heteroscedasticity was tested by White's General test for heteroscedasticity. All of these tests were conducted using the Gnu Regression, Econometrics, and Time-series Library (GRETLE) software. Upon confirming that the models do not exhibit signs of autocorrelation and heteroscedasticity and establishing the statistical significance of the $\alpha$ coefficients at $0=0.05^{18}$.

The period observed by this paper is relatively limited but is in line with the aims of this article. Another issue is perhaps that the overall multiplicative effect of FDI on the economy might be underestimated, yet the net inflation corrected values were considered for all four variables observed in the model. Adding a constant to the values for Indonesia is perhaps the simplest solution that still preserves the linear relationship between the variables, but by adding a constant, it complicates any contribution this model might have in hypothesis testing or making statistically significant predictions.

\section{Results and Discussion}

The ADF test was conducted and all variables are stationary at $\mathrm{p}=0.1$. The null hypothesis of the ADF test is nonstationary and as such, if the test statistic value is significant it is possible to reject the null hypothesis of non-stationary and accept the alternative hypothesis of stationary. In the values for all of the variables that were observed in this model, the asymptotic $\mathrm{p}$-value of the test statistic is smaller than 0.1 . This leads to the conclusion that at $\mathrm{p}=0.1$, it is possible to reject the null hypothesis of non-stationary and confirm the alternative hypothesis of stationary. A summarized table is provided, while the full output provided by GRETL may be found in the Appendix.

Table 2: Summary table of the ADF test

\begin{tabular}{|c|c|c|c|c|}
\hline Variable & $\begin{array}{c}\text { Number of } \\
\text { lags }^{19}\end{array}$ & Test statistic value & Asymptotic p-value & Conclusion \\
\hline$\Delta$ log GDP Turkey & 2 & -3.55496 & 0.05792 & Stationary at $\mathrm{p}=0.1$ \\
\hline$\Delta \log$ FDI Turkey & 2 & -4.06519 & 0.02148 & Stationary at $\mathrm{p}=0.05$ \\
\hline$\Delta \log$ PC Turkey & 2 & -3.58145 & 0.05511 & Stationary at $\mathrm{p}=0.1$ \\
\hline$\Delta \log$ GC Turkey & 2 & -3.57845 & 0.05542 & Stationary at $\mathrm{p}=0.1$ \\
\hline$\Delta \log$ GDP Mexico & 2 & -4.32216 & 0.002845 & Stationary at $\mathrm{p}=0.01$ \\
\hline$\Delta \log$ FDI Mexico & 2 & -7.84663 & $6.206 \mathrm{e}-012$ & Stationary at $\mathrm{p}=0.01$ \\
\hline$\Delta \log$ PC Mexico & 2 & -4.22862 & 0.003983 & Stationary at $\mathrm{p}=0.01$ \\
\hline$\Delta \log$ GC Mexico & 2 & -6.52514 & 5.248 e- 008 & Stationary at $\mathrm{p}=0.01$ \\
\hline$\Delta \log$ GDP Nigeria & 2 & -4.91629 & 0.000262 & Stationary at $\mathrm{p}=0.01$ \\
\hline$\Delta \log$ FDI Nigeria & 2 & -5.56339 & 0.0009571 & Stationary at $\mathrm{p}=0.01$ \\
\hline$\Delta \log$ PC Nigeria & 2 & -4.22845 & 0.01544 & Stationary at $\mathrm{p}=0.05$ \\
\hline$\Delta \log$ GC Nigeria & 2 & -6.23776 & 0.0002351 & Stationary at $\mathrm{p}=0.01$ \\
\hline$\Delta \log$ GDP Indonesia & 2 & -4.70369 & 0.005532 & Stationary at $\mathrm{p}=0.01$ \\
\hline$\Delta \log$ FDI Indonesia & 2 & -7.25802 & $2.962 \mathrm{e}-005$ & Stationary at $\mathrm{p}=0.01$ \\
\hline$\Delta \log$ PC Indonesia & 2 & -5.14814 & 0.002293 & Stationary at $\mathrm{p}=0.01$ \\
\hline$\Delta \log$ GC Indonesia & 2 & -4.58779 & 0.007381 & Stationary at $\mathrm{p}=0.01$ \\
\hline
\end{tabular}

Source: Authors' calculation and GRETL output

\footnotetext{
${ }^{17}$ Thevalue of the $\beta$ coefficient is 16608121666 , and the exact absolute value that was needed to make all of the FDI net inflow values positive was 16608121665.908 .

${ }^{18}$ Seeing, as the purpose of this article is to compare the value of the coefficients in the model rather than to predict any statistically significant results, there is no need to test for normality of residuals. The test was conducted despite the previously stated fact in order to test further potential of the models.

${ }^{19}$ The number of lags was automatically chosen by GRETL. The low value of the first order autocorrelation coefficient that can be viewed in the Appendix, clearly displays that the correct number of lags was used.
} 
The stationarity of all of the variables was confirmed, and the OLS models for all of the MINT countries can, therefore, be considered. As can be seen in Model 1, the only $\alpha$ coefficient that is statistically significant is $\alpha_{2}$, which indicates an absolute value of private consumption for the GDP growth of Turkey. White's test for heteroscedastic confirms the null hypothesis at $\mathrm{p}=0.05$ meaning that heteroscedasticity is not present; the LM test confirms that there is no presence of autocorrelation, and the errors are normally distributed.

Model 1: OLS, using observations 1992-2014 (T = 23) Turkey Dependent variable: ld_GDP

\begin{tabular}{|c|c|c|c|c|c|c|}
\hline & Coefficient & \multicolumn{2}{|c|}{ Std. Error } & t-ratio & $p$-value & \\
\hline const & -0.00452279 & \multicolumn{2}{|c|}{0.00588235} & -0.7689 & 0.4514 & \\
\hline ld_FDI & 0.00803372 & \multicolumn{2}{|c|}{0.00861503} & 0.9325 & 0.3628 & \\
\hline ld_GC & 0.0554345 & \multicolumn{2}{|c|}{0.063884} & 0.8677 & 0.3964 & \\
\hline ld_PC & 0.924105 & \multicolumn{2}{|c|}{0.0666338} & 13.8684 & $<0.0001$ & $* * * 20$ \\
\hline Mean dependent var & \multicolumn{2}{|c|}{-0.233896} & \multicolumn{2}{|c|}{ S.D. dependent var } & \multicolumn{2}{|r|}{0.318080} \\
\hline Sum squared resid & \multicolumn{2}{|c|}{0.009672} & \multicolumn{2}{|c|}{ S.E. of regression } & \multicolumn{2}{|r|}{0.022562} \\
\hline R-squared & \multicolumn{2}{|c|}{0.995655} & \multicolumn{2}{|c|}{ Adjusted R-squared } & \multicolumn{2}{|r|}{0.994969} \\
\hline $\mathrm{F}(3.19)$ & \multicolumn{2}{|c|}{1451.198} & \multicolumn{2}{|c|}{$\mathrm{P}$-value(F) } & \multicolumn{2}{|r|}{$1.31 \mathrm{e}-22$} \\
\hline Log-likelihood & \multicolumn{2}{|c|}{56.76578} & \multicolumn{2}{|c|}{ Akaike criterion } & \multicolumn{2}{|c|}{-105.5316} \\
\hline Schwarz criterion & \multicolumn{2}{|c|}{-100.9896} & \multicolumn{2}{|c|}{ Hannan-Quinn } & \multicolumn{2}{|c|}{-104.3893} \\
\hline rho & \multicolumn{2}{|c|}{-0.136241} & \multicolumn{2}{|c|}{ Durbin-Watson } & \multicolumn{2}{|r|}{2.165066} \\
\hline
\end{tabular}

White's test for heteroscedasticity -

Null hypothesis: heteroscedasticity not present

Test statistic: $\mathrm{LM}=15.8384$

with p-value $=\mathrm{P}($ Chi-square $(9)>15.8384)=0.0703337$

LM test for autocorrelation up to order 1 -

Null hypothesis: no autocorrelation

Test statistic: $\mathrm{LMF}=0.353533$

with $p$-value $=\mathrm{P}(\mathrm{F}(1.18)>0.353533)=0.55952$

Test for normality of residual -

Null hypothesis: error is normally distributed

Test statistic: Chi-square(2) $=1.5421$

with p-value $=0.462527$

Source: Authors' calculation and GRETL output

In Model 2, the value of the coefficients for Mexico was considered. A similar trait is that Mexico and Turkey are highly dependent upon private consumption. For Turkey the only coefficient that was statistically significant at $\mathrm{p}=0.1$ was private consumption, implying its very high relevance for the Turkish economy. While private consumption has a very significant effect on the Mexican economy, at $\mathrm{p}=0.05$ the $\alpha_{3}$ coefficient is also statistically significant. Therefore, while the Turkish economy is mostly dependent upon private consumptions ${ }^{21}$, the Mexican economy is also dependent - albeit to a lesser degree, both in the private and government consumption. The R-squared value for these models displays that the explanatory variables were appropriately selected, and the explanatory value of the chosen model is very high. ${ }^{22}$ White's test for heteroscedasticity confirms the null hypothesis at $\mathrm{p}=0.3869$, meaning that heteroscedasticity is not present. The LM test, as well as the value of the Durbin-Watson statistic, clearly display that the model does not have autocorrelation issues.

\footnotetext{
${ }^{20}$ Indicates level of significance at the respected $0.1,0.5$ and 0.01 levels.

${ }^{21}$ Out of the three chosen explanatory variables.

${ }^{22}$ The R-squared value is the ability of the model to predict how changes in the independent variables - in the case of these models FDI, private and government consumption, affect GDP change. Therefore for these two models 0.9957 and 0.9949 of the changes can be explained by these models.
} 
Filip Kokotović, Petar Kurečić

The Mint Countries: A Regression Analysis of the Selected Economic Features

Model 2: OLS, using observations 1992-2014 ( $\mathrm{T}=23)$ Mexico Dependent variable: ld_GDP

\begin{tabular}{|c|c|c|c|c|c|c|}
\hline & Coefficient & \multicolumn{2}{|c|}{ Std. Error } & t-ratio & \multicolumn{2}{|l|}{$p$-value } \\
\hline const & -0.00223632 & \multicolumn{2}{|c|}{0.00270695} & -0.8261 & 0.4190 & \\
\hline ld_FDI & -0.00691364 & \multicolumn{2}{|c|}{0.00778145} & -0.8885 & 0.3854 & \\
\hline ld_GC & 0.0804238 & \multicolumn{2}{|c|}{0.0381248} & 2.1095 & 0.0484 & $* *$ \\
\hline ld_PC & 0.848133 & \multicolumn{2}{|c|}{0.0382026} & 22.2009 & $<0.0001$ & $* * *$ \\
\hline Mean dependent var & \multicolumn{2}{|c|}{-0.038236} & \multicolumn{2}{|c|}{ S.D. dependent var } & \multicolumn{2}{|r|}{0.163043} \\
\hline Sum squared resid & \multicolumn{2}{|c|}{0.002986} & \multicolumn{2}{|c|}{ S.E. of regression } & \multicolumn{2}{|r|}{0.012535} \\
\hline R-squared & \multicolumn{2}{|c|}{0.994895} & \multicolumn{2}{|c|}{ Adjusted R-squared } & \multicolumn{2}{|r|}{0.994089} \\
\hline $\mathrm{F}(3.19)$ & \multicolumn{2}{|c|}{1234.273} & \multicolumn{2}{|c|}{ P-value(F) } & \multicolumn{2}{|r|}{$6.07 e-22$} \\
\hline Log-likelihood & \multicolumn{2}{|c|}{70.28320} & \multicolumn{2}{|c|}{ Akaike criterion } & \multicolumn{2}{|c|}{-132.5664} \\
\hline Schwarz criterion & \multicolumn{2}{|c|}{-128.0244} & \multicolumn{2}{|c|}{ Hannan-Quinn } & \multicolumn{2}{|c|}{-131.4241} \\
\hline rho & \multicolumn{2}{|c|}{-0.005032} & \multicolumn{2}{|c|}{ Durbin-Watson } & \multicolumn{2}{|r|}{1.840216} \\
\hline \multicolumn{7}{|c|}{ White's test for heteroscedasticity - } \\
\hline \multicolumn{7}{|c|}{ Null hypothesis: heteroscedasticity not present } \\
\hline \multicolumn{7}{|l|}{ Test statistic: $\mathrm{LM}=9.56371$} \\
\hline \multicolumn{7}{|c|}{ with $\mathrm{p}$-value $=\mathrm{P}($ Chi-square $(9)>9.56371)=0.386945$} \\
\hline \multicolumn{7}{|c|}{ LM test for autocorrelation up to order $1-$} \\
\hline Null hypothesis: no autocor & tion & & & & & \\
\hline Test statistic: $\mathrm{LMF}=0.0005$ & 784 & & & & & \\
\hline with $p$-value $=P(F(1.18)>$ & $00537784)=0$. & 31754 & & & & \\
\hline Test for normality of residua & & & & & & \\
\hline Null hypothesis: error is nor & lly distributed & & & & & \\
\hline Test statistic: Chi-square(2) & .31648 & & & & & \\
\hline with $\mathrm{p}$-value $=0.517762$ & & & & & & \\
\hline
\end{tabular}

Source: Authors' calculation and GRETL output

Model 3: OLS, using observations 1992-2014 ( $\mathrm{T}=23)$ Nigeria Dependent variable: ld_GDP

\begin{tabular}{|c|c|c|c|c|c|c|}
\hline & Coefficient & \multirow{2}{*}{\multicolumn{2}{|c|}{$\begin{array}{l}\text { Std. Error } \\
0.0292826\end{array}$}} & $t$-ratio & \multirow{2}{*}{$\begin{array}{c}p \text {-value } \\
0.3955\end{array}$} & \\
\hline const & -0.0254586 & & & -0.8694 & & \\
\hline 1d_FDI & -0.0686506 & & 877 & -0.9563 & 0.3509 & \\
\hline ld_GC & 0.183209 & & & 2.1521 & 0.0445 & $* *$ \\
\hline ld_PC & 0.617862 & & & 4.9096 & $<0.0001$ & $* * *$ \\
\hline \multicolumn{2}{|l|}{ Mean dependent var } & -0.057564 & \multicolumn{2}{|c|}{ S.D. dependent var } & & 0.226800 \\
\hline \multicolumn{2}{|l|}{ Sum squared resid } & 0.339159 & S.E & ssion & & 0.133606 \\
\hline \multicolumn{2}{|l|}{ R-squared } & 0.700293 & $\mathrm{Ad}$ & squared & & 0.652971 \\
\hline \multicolumn{2}{|l|}{$\mathrm{F}(3.19)$} & 14.79841 & $\mathrm{P}-\mathrm{v}$ & & & 0.000033 \\
\hline \multicolumn{2}{|l|}{ Log-likelihood } & 15.85737 & $\mathrm{Ak}$ & rion & & -23.71475 \\
\hline \multicolumn{2}{|l|}{ Schwarz criterion } & -19.17277 & $\mathrm{Hat}$ & & & -22.57245 \\
\hline \multicolumn{2}{|l|}{ rho } & -0.041131 & $\mathrm{Du}$ & son & & 2.004275 \\
\hline $\begin{array}{l}\text { White's test for heteroscedasticity - } \\
\text { Null hypothesis: heteroscedasticity not } \\
\text { Test statistic: } \mathrm{LM}=10.9583 \\
\text { with p-value }=\mathrm{P}(\mathrm{Chi} \text {-square }(9)>10.95 \\
\text { LM test for autocorrelation up to order } \\
\text { Null hypothesis: no autocorrelation } \\
\text { Test statistic: } \mathrm{LMF}=0.0377467 \\
\text { with p-value }=\mathrm{P}(\mathrm{F}(1.18)>0.0377467) \\
\text { Test for normality of residual - } \\
\text { Null hypothesis: error is normally distr } \\
\text { Test statistic: Chi-square }(2)=2.35119 \\
\text { with p-value }=0.308635\end{array}$ & $\begin{array}{l}\text { resent } \\
3)=0.278576 \\
=0.848129 \\
\text { uted }\end{array}$ & & & & & \\
\hline
\end{tabular}

Source: Source: Authors' calculation and GRETL output 
In Model 3, the economy of Nigeria was considered. The first thing that should be noted is that the explanatory value of the model is not as high as in the cases of Mexico and Turkey. With the R-squared value of 0.700293, the model can predict only about $70 \%$ of the changes that occur on the regression line based upon the changes of the independent variable. Taking into account the economy of Nigeria and its high dependence on oil export, perhaps adding a variable that measures net export might enhance the explanatory value of the model. Viewing the model in the context of the other MINT countries, Nigeria does not seem to have a statistically significant effect of FDI on GDP growth, while the most significant variable in predicting GDP change is private consumption, with a far more significant influence of government use on GDP change than in Mexico and Turkey.

The final model considers the economic growth of Indonesia. The explanatory value of the model is as high as was the case with Turkey and Mexico, which indicates that despite the comparatively small value of R-squared for the Nigerian model, the explanatory variables were adequately selected. FDI does not have a statistically significant positive impact on GDP growth in any of the considered models. The regression results for Indonesia suggest that government consumption and private consumption have approximately the same impact on GDP growth, which differs significantly in comparison to the other MINT countries. No issues regarding heteroskedasticity or autocorrelation were detected based upon the LM test, White's test and the Durbin-Watson statistic value.

Model 4: OLS, using observations 1992-2014 (T = 23) Indonesia Dependent variable: ld_GDP

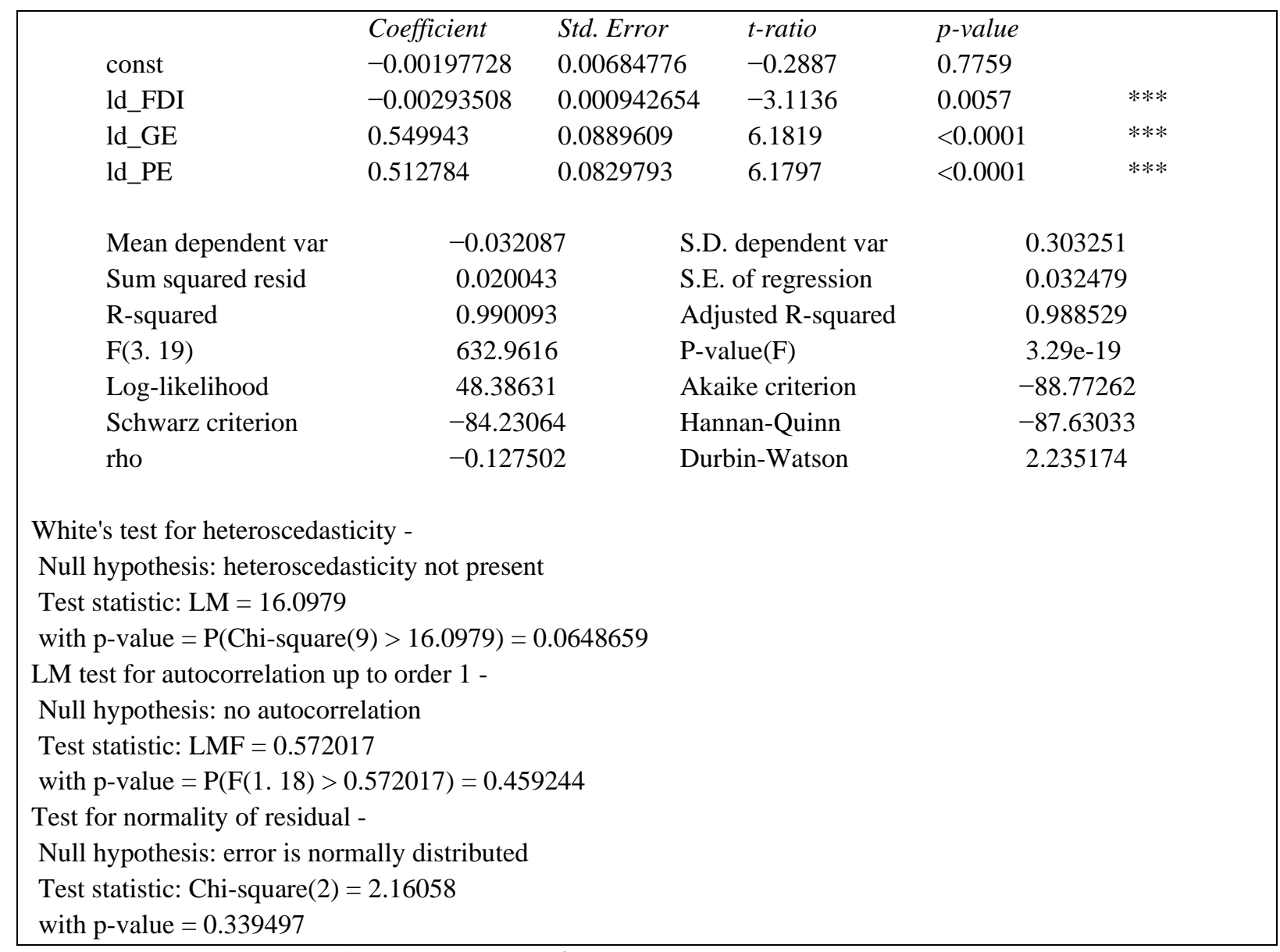

Source: Source: Authors' calculation and GRETL output

\section{Conclusion}

The MINT economies represent emerging and rapidly growing economies, albeit with very significant differences. These countries will be more and more important for the world economy and the world in general. The crucial geostrategic position of Turkey will always boost its significance. The strategic value of Nigerian oil will exist as long as there is oil in Nigeria. Besides that, Nigeria is the only country that fulfills the role of stabilizer in the Western Africa and the Gulf of Guinea region. The central, albeit also disperse geographic position of Indonesia in the part of the Asia-Pacific Rim between South-East Asia and Australia, due to the increased Chinese ambitions and the US 
presence in this maritime region means that Indonesia is vital, strategically and politically, even now. Mexico can position itself as a land bridge between North and South America, and use its resources and relatively cheap labor force to boost its development. However, the MINT is not the new BRICS, and they never will be. They just lack the size, as well as the economic, political, and military power. The MINT countries can (and very likely will be) be regional powers and the economic powerhouses among the emerging economies, but hardly anything more than that, which is nevertheless a remarkable improvement if we compare it to their relative political significance and economic power from a couple of decades ago.

\section{References}

- $\quad$ Akpan, U., Salisu, I., Asongu, S. (2014). Determinants of Foreign Direct Investment in Fast-Growing Economies: A Study of BRICS and MINT. AAYE Policy Research Working Paper Series, 14, Association of Young African Economists, http://econpapers.repec.org/paper/aaywpaper/14_5f014.htm (Retrieved 18/03/2016).

- Carson, R.T. (2010). The Environmental Kuznets Curve: Seeking Empirical Regularity and Theoretical Structure. Review of Environmental Economics and Policy, 4 (1) 3-23, CorssRef

- Dickey, D.A, Fuller, W.A. (1979). Distribution of the Estimators for Autoregressive Time Series with a Unit Root. Journal of the American Statistical Association 74:427-431, CorssRef, $\underline{\text { CorssRef }}$

- Durotoye, A. (2014a). The MINT Countries as Emerging Economic Power Bloc: Prospects and Challenges. Developing Country Studies, 4 (15) 99-106

- Durotoye, A. (2014b). The Crisis of Youth Unemployment in the MINT Countries: Causes, Consequences, and Corrections. European Journal of Business and Management, 6 (24) 123-135.

- Kurečić, P., Kozina, G. (2014). Natural Resources Management as a Factor of Underdevelopment and Social Inequality in the Gulf of Guinea Region. Proceedings of the Eighth International Scientific Conference on Economic and Social Development and fourth Eastern European ESD Conference: Building Resilient Economy, Zagreb, Croatia: 118-127, http://www.esd-conference.com/Book_of_Proceedings_esd_ZG_2014.pdf.

- Öztürk, Z., Yildirim, E. (2015). Environmental Kuznets Curve in the MINT Countries: Evidence of Long-Run Panel Causality Test. The International Journal of Economic and Social Research, 11 (1) 175-183.

- Simplice, A.A. (2015). Drivers of Growth in Fast Emerging Economies: A Dynamic Instrumental Quantile Approach. African Governance and Development Institute Working Paper, 15/009

- Watts, M. (2004). Resource curse? Governmentality, oil and power in the Niger Delta. Geopolitics, 9 (1) 50-80, CrossRef

- http://www.bbc.com/news/magazine-25548060 (Retrieved 16/03/2016).

- http://www.cambashi.com/contentmgr/showdetails.php/id/2513/page/3 (Retrieved 20/03/2016).

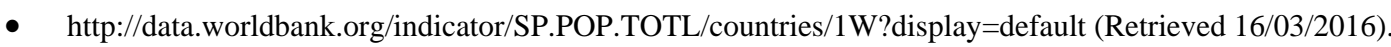

- http://data.worldbank.org/indicator/NY.GDP.MKTP.CD/countries/1W?display=default (Retrieved 16/03/2016).

- http://www.geopoliticalmonitor.com/backgrounder-mist-countries-4746/ (Retrieved 17/03/2016).

- http://money.cnn.com/2015/08/18/news/countries-with-biggest-populations/ (Retrieved 16/03/2016).

- http://www.theneweconomy.com/business/is-mint-the-next-bric (Retrieved 17/03/2016).

- $\quad$ http://www.tmf-group.com/en/media-centre/news-and-insights/january-2014/refreshing-economic-news-mint-is-the-newbrics (Retrieved 20/03/2016)

\section{Appendix}

The first set of ADF tests for the variables for Turkey.

\begin{tabular}{|c|c|}
\hline $\begin{array}{l}\text { Augmented Dickey-Fuller test for ld_GDP } \\
\text { including one lag of (1-L)ld_GDP } \\
\text { (max was } 2 \text {. criterion AIC) } \\
\text { sample size } 21 \\
\text { unit-root null hypothesis: a = } 1 \\
\text { with constant and trend } \\
\text { model: }(1-\mathrm{L}) \mathrm{y}=\mathrm{b} 0+\mathrm{b} 1 * \mathrm{t}+(\mathrm{a}-1) * \mathrm{y}(-1)+\mathrm{e} \\
\text { estimated value of }(\mathrm{a}-1):-0.821038 \\
\text { test statistic: tau_ct }(1)=-3.55496 \\
\text { p-value } 0.05792 \\
\text { 1st-order autocorrelation coeff. for e: }-0.052\end{array}$ & $\begin{array}{l}\text { Augmented Dickey-Fuller test for ld_FDI } \\
\text { including } 0 \text { lags of }(1-\mathrm{L}) \mathrm{ld} \text { _FDI } \\
\text { (max was } 2 \text {. criterion AIC) } \\
\text { sample size } 22 \\
\text { unit-root null hypothesis: } \mathrm{a}=1 \\
\text { with constant and trend } \\
\text { model: }(1-\mathrm{L}) \mathrm{y}=\mathrm{b} 0+\mathrm{b} 1 * \mathrm{t}+(\mathrm{a}-1) * \mathrm{y}(-1)+\mathrm{e} \\
\text { estimated value of }(\mathrm{a}-1):-0.934727 \\
\text { test statistic: tau_ct }(1)=-4.06519 \\
\text { p-value } 0.02148 \\
\text { 1st-order autocorrelation coeff. for e: } 0.005\end{array}$ \\
\hline
\end{tabular}




\begin{tabular}{|l|l|}
\hline Augmented Dickey-Fuller test for ld_GC & Augmented Dickey-Fuller test for ld_PC \\
including 2lags of (1-L)ld_GC & including one lag of (1-L)ld_PC \\
(max was 2. criterion AIC) & (max was 2. criterion AIC) \\
sample size 20 & sample size 21 \\
unit-root null hypothesis: $\mathrm{a}=1$ & unit-root null hypothesis: $\mathrm{a}=1$ \\
with constant and trend & with constant and trend \\
model: $(1-\mathrm{L}) \mathrm{y}=\mathrm{b} 0+\mathrm{b} 1 * \mathrm{t}+(\mathrm{a}-1) * \mathrm{y}(-1)+\mathrm{e}$ & model: $(1-\mathrm{L}) \mathrm{y}=\mathrm{b} 0+\mathrm{b} 1 * \mathrm{t}+(\mathrm{a}-1) * \mathrm{y}(-1)+\mathrm{e}$ \\
estimated value of $(\mathrm{a}-1):-0.820811$ & estimated value of $(\mathrm{a}-1):-0.836146$ \\
test statistic: tau_ct $(1)=-3.57845$ & test statistic: tau_ct $(1)=-3.58145$ \\
p-value 0.05542 & p-value 0.05511 \\
1st-order autocorrelation coeff. for e: -0.038 & 1st-order autocorrelation coeff. for e: -0.037 \\
\hline
\end{tabular}

Source: Authors' calculation and GRETL output

The second set of ADF tests for the variables for Mexico.

\begin{tabular}{|c|c|}
\hline $\begin{array}{l}\text { Augmented Dickey-Fuller test for ld_GDP } \\
\text { including } 0 \text { lags of }(1-L) l d \_G D P \\
\text { (max was } 2 \text {. criterion AIC) } \\
\text { sample size } 22 \\
\text { unit-root null hypothesis: a }=1 \\
\text { with constant and trend } \\
\text { model: }(1-\mathrm{L}) \mathrm{y}=\mathrm{b} 0+\mathrm{b} 1 * \mathrm{t}+(\mathrm{a}-1) * \mathrm{y}(-1)+\ldots+\mathrm{e} \\
\text { estimated value of }(\mathrm{a}-1):-1.3662 \\
\text { test statistic: tau_ct }(1)=-4.32216 \\
\text { asymptotic p-value } 0.002845 \\
\text { 1st-order autocorrelation coeff. for e: }-0.128\end{array}$ & $\begin{array}{l}\text { Augmented Dickey-Fuller test for ld_FDI } \\
\text { including one lag of (1-L)ld_FDI } \\
\text { (max was } 2 \text {. criterion AIC) } \\
\text { sample size } 21 \\
\text { unit-root null hypothesis: a = } 1 \\
\text { with constant and trend } \\
\text { model: }(1-\mathrm{L}) \mathrm{y}=\mathrm{b} 0+\mathrm{b} 1 * \mathrm{t}+(\mathrm{a}-1) * \mathrm{y}(-1)+\ldots+\mathrm{e} \\
\text { estimated value of }(\mathrm{a}-1):-2.49415 \\
\text { test statistic: tau_ct }(1)=-7.84663 \\
\text { asymptotic p-value } 6.206 \mathrm{e}-012 \\
\text { 1st-order autocorrelation coeff. for e: } 0.153\end{array}$ \\
\hline $\begin{array}{l}\text { Augmented Dickey-Fuller test for ld_GC } \\
\text { including one lag of }(1-\mathrm{L}) \mathrm{ld} \_\mathrm{GC} \\
\text { (max was } 2 \text {. criterion AIC) } \\
\text { sample size } 21 \\
\text { unit-root null hypothesis: a }=1 \\
\text { with constant and trend } \\
\text { model: }(1-\mathrm{L}) \mathrm{y}=\mathrm{b} 0+\mathrm{b} 1 * \mathrm{t}+(\mathrm{a}-1) * \mathrm{y}(-1)+\ldots+\mathrm{e} \\
\text { estimated value of }(\mathrm{a}-1):-1.322 \\
\text { test statistic: tau_ct }(1)=-6.52514 \\
\text { asymptotic p-value } 5.248 \mathrm{e}-008 \\
\text { 1st-order autocorrelation coeff. for e: }-0.276\end{array}$ & $\begin{array}{l}\text { Augmented Dickey-Fuller test for ld_PC } \\
\text { including } 0 \text { lags of (1-L)ld_PC } \\
\text { (max was } 2 \text {. criterion AIC) } \\
\text { sample size } 22 \\
\text { unit-root null hypothesis: a = } 1 \\
\text { with constant and trend } \\
\text { model: }(1-\mathrm{L}) \mathrm{y}=\mathrm{b} 0+\mathrm{b} 1 * \mathrm{t}+(\mathrm{a}-1) * \mathrm{y}(-1)+\ldots+\mathrm{e} \\
\text { estimated value of }(\mathrm{a}-1):-1.37453 \\
\text { test statistic: tau_ct }(1)=-4.22862 \\
\text { asymptotic p-value } 0.003983 \\
\text { 1st-order autocorrelation coeff. for e: }-0.112\end{array}$ \\
\hline
\end{tabular}

Source: Authors' calculation and GRETL output

The third set of tests for the variables for Nigeria.

\begin{tabular}{|l|l|}
\hline Augmented Dickey-Fuller test for ld_GDP & $\begin{array}{l}\text { Augmented Dickey-Fuller test for ld_FDI } \\
\text { including one lag of }(1-\mathrm{L}) \mathrm{ld} \_G D P\end{array}$ \\
(max was 2. criterion AIC) & (max was 2. criterion AIC) \\
sample size 21 & sample size 22 \\
unit-root null hypothesis: $\mathrm{a}=1$ & unit-root null hypothesis: $\mathrm{a}=1$ \\
with constant and trend & with constant and trend \\
model: $(1-\mathrm{L}) \mathrm{y}=\mathrm{b} 0+\mathrm{b} 1 * \mathrm{t}+(\mathrm{a}-1)^{*} \mathrm{y}(-1)+\ldots+\mathrm{e}$ & model: $(1-\mathrm{L}) \mathrm{y}=\mathrm{b} 0+\mathrm{b} 1 * \mathrm{t}+(\mathrm{a}-1) * \mathrm{y}(-1)+\mathrm{e}$ \\
estimated value of $(\mathrm{a}-1):-0.715347$ & estimated value of $(\mathrm{a}-1):-1.24033$ \\
test statistic: tau_ct $(1)=-4.91629$ & test statistic: tau_ct $(1)=-5.56339$ \\
asymptotic p-value 0.000262 & p-value 0.0009571 \\
1st-order autocorrelation coeff. for e: -0.012 & 1st-order autocorrelation coeff. for e: -0.019 \\
\hline
\end{tabular}




\begin{tabular}{|l|l|}
\hline Augmented Dickey-Fuller test for ld_GC & Augmented Dickey-Fuller test for ld_PC \\
including 0 lags of (1-L)ld_GC & including 0 lags of (1-L)ld_PC \\
(max was 2. criterion AIC) & (max was 2. criterion AIC) \\
sample size 22 & sample size 22 \\
unit-root null hypothesis: $\mathrm{a}=1$ & unit-root null hypothesis: $\mathrm{a}=1$ \\
with constant and trend & with constant and trend \\
model: $(1-\mathrm{L}) \mathrm{y}=\mathrm{b} 0+\mathrm{b} 1 * \mathrm{t}+(\mathrm{a}-1) * \mathrm{y}(-1)+\mathrm{e}$ & model: $(1-\mathrm{L}) \mathrm{y}=\mathrm{b} 0+\mathrm{b} 1 * \mathrm{t}+(\mathrm{a}-1) * \mathrm{y}(-1)+\mathrm{e}$ \\
estimated value of $(\mathrm{a}-1):-1.3434$ & estimated value of $(\mathrm{a}-1):-0.974853$ \\
test statistic: tau_ct $(1)=-6.23776$ & test statistic: tau_ct $(1)=-4.22845$ \\
p-value 0.0002351 & p-value 0.01544 \\
1 st-order autocorrelation coeff. for e: -0.110 & 1st-order autocorrelation coeff. for e: -0.076 \\
\hline
\end{tabular}

Source: Authors' calculation and GRETL output

The final set of tests considers the stationary of the variables for Indonesia.

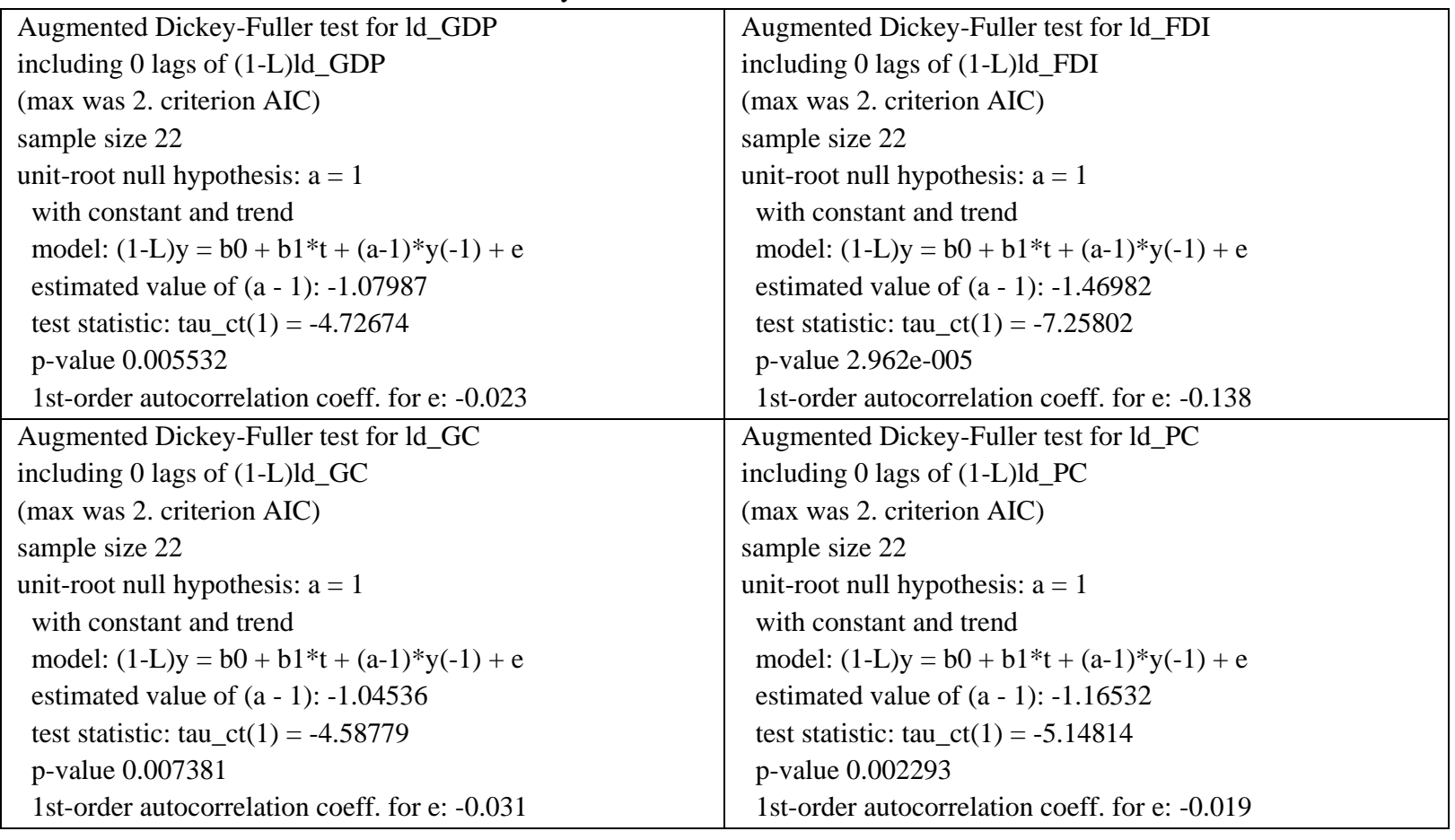

Source: Authors' calculation and GRETL output 